\title{
The Effect of Working Capital on the Profitability in Property and Real Estate Companies Listed on The Indonesian Stock Exchange (IDX)
}

\author{
Gebrie Dwi Irhamna ${ }^{1,}$ Erni Masdupi ${ }^{2}$ \\ ${ }^{12}$ Department Management, Economic Faculty, Universitas Negeri Padang \\ *Coresponding author. Email: gebrie0391@gmail.com
}

\begin{abstract}
This research aims to review the influence of working capital on profitability in the property and real estate companies listed on the Indonesian Stock Exchange (IDX) by using secondary data. The sampling technique used purposive sampling. The number of samples in this study were 230 observations (46 companies with 5 years of research). The data analysis method used is ordinary least square (OLS) analysis assisted by SPSS 16. This study adds control variables to measure the resilience of variable relationships. The results of the study concluded that the working capital variable measured using cash management or cash conversion cycle (CCC) had a positive and insignificant effect on profitability using the control variable. Working capital variables measured using receivable management (receivable collection period) have a negative and significant effect on profitability using control variables. The working capital variable measured using inventory management (inventory conversion period) has no effect on profitability using the control variable. Working capital variables measured using debt management (account payable period) have a negative and significant effect on profitability using control variables.
\end{abstract}

Keywords: Working Capital, Profitability, and Control Variables

\section{INTRODUCTION}

The main objective of the company is to attract the attention of investors to the business world. The company's business should be able to provide advantages between company management and shareholders so that it can win the competition. When the company has become an attraction for investors, competitors will emerge so that management must have programs that are able to keep investors in the company. Company management can provide information about how it is managed based on the results or performance obtained at the end of the year.

Before investing, investors will assess the feasibility of the company so that it can minimize the risk of loss in the future. Investors will assess whether the company has a high performance so that it will provide a return on the investment made. The assessment of the company can be seen from the financial activities reported in the company's financial statements. Investors cannot conduct direct appraisals into the company due to limited access, so they can only see based on information that has been published by the company's management through its annual report. For this reason, investors can conduct analysis based on financial theories by using the accounts contained in the company's annual report.

Management and investors must pay attention to any economic changes that occur, both globally and nationally. Economy change would have an impact on the continuity of the company and must be considered carefully. According to Mun \& Jang [1], economic changes result in uncertainty in economic policies that have a negative impact on company operations. To overcome this impact requires in-depth analysis through the accounts in the annual report such as profit and income.

According to Abuzayed [2], in general, when the financial crisis occurs it will cause management to focus on short-term investments with maturities of less than one year. Short-term investments can represent the main items on the statement of financial position that can change the company's capital position. Company management will focus on efforts to generate returns on short-term investments so that it will reduce the risk of liquidation. Companies can use the income through these 
investments to cover losses due to the financial crisis. So that information manipulation will be created that is not in accordance with reality. Companies that actually have a decline in performance can be minimized by short-term investment activities.

Measurement of profit can be seen through profitability. According to Abuzayed [2], profitability is a decision made regarding operations that have a very important role in business. Given that business must be conducted profitably and run efficiently so as to impose limits on liabilities and capital to meet the rapid turnover of products and services. This can lead to an accumulation of capital in certain stocks. Profitability can describe management performance, namely being able to increase company profits in the financial reporting period. Companies that have a high level of profitability will tend to be considered a good company by investors or management so that they can be said to have achieved the company's main goals.

According to Mabandla \& Makoni [3], the profitability ratio is production against financial performance measurements such as return on assets which measures income before tax based on total assets. Profitability ratios can tell about the asset base or other indicators used by the company to generate profits. The measurement of the profitability ratio is the main proxy in seeing whether the company is performing well or not. The better the level of profitability of a company, the more interested investors will be to invest in the company so that management is considered capable of controlling the company well.

According to Omoregie et al. [4], financial sources are divided into two sources, namely internal sources and external sources. Internal sources are obtained from retained earnings without cost, while external sources come from capital and debt. The balance of funding sources will result in efficiency in increasing the company's profitability. Increased profitability is created through operational activities funded by external and internal sources. So the better the management of the source of funds, the better the profitability will be based on the company's financial capability.

According to Raheman et al. [5], the trade off theory explains that profitability is very important if working capital management is not provided because of certain considerations so that the company can be said to be failing and will face bankruptcy. Management of working capital needs to be done properly to produce a level of profitability for the company so that working capital is closely related to company performance, which is measured by the level of profitability.

According to Al-Debi'e [6], theory of trade off between risk and return explained that working capital management will focus on the quality of current assets and consider the opportunities between risk and return. The quality of current assets will depend largely on the current asset composition and the time period required to convert individual assets into cash. The quality of working capital can consider whether a current asset is sufficient to cover the company's current liabilities. Consideration of the quality of working capital will giving effect on management of profitability because taking into account current assets and all related items such as debt and capital will be able to increase company sales, as well as reduce costs so that it will increase profits.

According to Sin et al. [7], the pecking order theory explains that there are costs to external financing and increased attention to creditors and shareholders, so companies must use internal resources to get financing before looking for external resources. A higher debt increase for more efficient operations can be done if internal funding sources are no longer able to meet all of the company's operational activities. The pecking order theory explains that company management will use all sources of capital such as debt and capital so that operational activities can continue.

According to Mun \& Jang [1], Working capital is the difference between current assets and current liabilities which is used to measure the level of liquidity of a company. The components contained in working capital are cash, accounts receivable, inventories, accounts payable, current debts, and long-term debt. Working capital is the maximization of current assets and current liabilities of the company to measure the level of liquidity which is a reference for management performance.

According to Sin et al. [7], the importance of working capital is to ensure the use of capital to generate profitability in the future. Working capital management is the integration of components of the overall strategy towards the efficient use of capital to create corporate value in the future. Basically, working capital management measures cash management (cash conversion cycle), receivable management (receivable collection period), inventory management (inventory conversion period), and debt management (account payable period).

According to Sin et al. [7], the cash conversion cycle (CCC) is a measure that is very commonly used in measuring the efficiency of working capital. A longer investment period in working capital will force companies to seek external financing. The process of searching for external sources of financing is quite costly. The main objective of cash management is to minimize working capital in providing funds to support daily operations. This means that cash management describes the management of cash flow where management must manage the gauze flow efficiently and effectively to improve company operations. The better cash management, the more efficient the use of funds to support these operations. Good cash management can reduce the cost of finding other sources of external financing to increase support for operations. The better cash management, the company is considered capable of controlling cash flow on the value of investment in 
working capital so that it is expected to increase the company's profitability.

According to Harmono [8], investment in working capital accounts for accounts receivable can arise from the sale of credit and the level of accounts receivable investment depends on credit policies and the receivables collection system in conjunction with stimulation of increased sales. Offers of credit on sales have an impact on reducing the price that comes from direct deductions such as sales discounts when receivables are paid in a certain period and indirect deductions resulting from investing funds that are embedded in receivables until their maturity date. As a result of this reduction, the company's revenue will decrease so that the profit received will also decrease. The more receivables that are embedded in a company, the less likely the company will receive cash flow in a short time so that the company's revenue will decrease and it can reduce its profitability.

According to Simon et al. [9], receivables management or receivable collection period (RCP) has a negative relationship with profitability because of the large amount of retained funds that should be revenue for the company. The negative impact arising from receivables occurs because of the pile of working capital funding that is withheld for a certain period of time so that the potential for sales to become cash flow is longer. As a result, the higher the receivables, the lower the company's profitability because the company's revenue that should be received in a short time becomes longer, even in the long term or more than one year.

According to Fahmi [10], inventory management or inventory conversion period (ICP) is the ability of a company to regulate and manage every need for goods, both raw goods, semi-finished goods, and finished goods so that they are always available in both stable and volatile market conditions. In order to realize a well and stable inventory, the company must apply a realistic inventory management concept that can be accepted by various parties.

According to Harmono [8], companies often store inventory in warehouses with the hope of reducing fixed costs arising from message costs or additional inventory costs due to a lack of anticipation for the amount of inventory needed in the production department. Additional costs can arise from the cost of storing goods in the warehouse and the increase in transportation costs, production costs, and the cost of determining the purchase order so that these costs can reduce the company's profitability. However, if the supply is low, the company will find it difficult to meet market needs so that it will reduce company revenue which will also result in reduced profitability. This means that inventory management must be anticipated and analyzed appropriately so that it is not too low or too high which will result in changes in the level of company profitability.

According to Fahmi [10], debt management or account payable period (APP) is the ability to analyze and oversee the implementation of obligations and payments in a timely manner. In the psychological concept of receivables management provides motivation to work creatively and innovatively on the grounds that there is a responsibility to pay installments on time every month. The company must be able to build a balance between needs and ability to pay debt because debt causes expenses that must be incurred by the company such as interest expenses which can reduce the profitability of company.

The phenomenon in property and real estate companies can be represented by the companies Agung Podomoro Land (APLN), Alam Sutera Reality (ASRI), and Bekasi Asri Pemula (BAPA), namely:

Table 1. The profitability values of the companies Agung Podomoro Land

\begin{tabular}{|c|c|c|c|c|c|c|c|}
\hline & Company Name & Variable & 2014 & 2015 & 2016 & 2017 & 2018 \\
\hline \multirow[t]{8}{*}{ APLN } & Agung Podomoro Land & ROA & 0.052 & 0.046 & 0.037 & 0.066 & 0.007 \\
\hline & & $\mathrm{CCC}$ & 433.153 & 486.577 & 498.462 & 396.794 & 512.134 \\
\hline & & $\mathrm{RCP}$ & 108.427 & 80.891 & 70.902 & 71.533 & 116.994 \\
\hline & & ICP & 489.364 & 541.966 & 555.081 & 420.295 & 516.769 \\
\hline & & APP & 164.639 & 136.281 & 127.521 & 95.034 & 121.630 \\
\hline & & LEV & 0.643 & 0.631 & 0.612 & 0.601 & 0.587 \\
\hline & & SIZE & 16.980 & 17.017 & 17.062 & 17.176 & 17.203 \\
\hline & & SG & 0.081 & 0.127 & 0.006 & 0.172 & -0.285 \\
\hline \multirow[t]{5}{*}{ ASRI } & Alam Sutera Reality & ROA & 0.082 & 0.041 & 0.029 & 0.070 & 0.049 \\
\hline & & $\mathrm{CCC}$ & 227.029 & 246.634 & 167.246 & 212.055 & 134.442 \\
\hline & & $\mathrm{RCP}$ & 14.501 & 22.639 & 23.688 & 20.155 & 21.453 \\
\hline & & $\mathrm{ICP}$ & 257.413 & 523.365 & 344.998 & 256.899 & 163.924 \\
\hline & & APP & 44.884 & 299.371 & 201.440 & 64.999 & 50.936 \\
\hline
\end{tabular}




\begin{tabular}{|r|l|l|r|r|r|r|r|}
\hline & & LEV & 0.624 & 0.647 & 0.644 & 0.586 & 0.540 \\
\hline & & SIZE & 16.644 & 16.745 & 16.821 & 16.847 & 16.859 \\
\hline & & SG & -0.014 & -0.233 & -0.024 & 0.442 & 0.015 \\
\hline BAPA & Bekasi Asri Pemula & ROA & 0.054 & 0.008 & 0.109 & 0.074 & 0.029 \\
\hline & & CCC & 2365.069 & 5669.039 & 4222.620 & 2974.519 & 3014.777 \\
\hline & & RCP & 2.711 & 4.664 & 1.733 & 1.254 & 0.064 \\
\hline & & ICP & 2434.332 & 5847.393 & 4339.201 & 3035.194 & 3323.211 \\
\hline & & APP & 71.975 & 183.018 & 118.314 & 61.929 & 308.498 \\
\hline & & LEV & 0.435 & 0.426 & 4.019 & 0.329 & 0.258 \\
\hline & & SIZE & 12.079 & 12.077 & 9.794 & 12.095 & 12.057 \\
\hline & & SG & 0.132 & -0.469 & 0.409 & 0.365 & -0.387 \\
\hline
\end{tabular}

Based on table 1, the profitability values of the companies Agung Podomoro Land, Alam Sutera Reality, and Bekasi Asri Pemula moved in a fluctuating direction and tended to decline in 2018 with ROA values only reaching 0.007, 0.049, and 0.029. A decrease in the level of profitability reflects a decrease in company profits which could potentially cause losses. The cash management of the companies Agung Podomoro Land and Bekasi Asri Pemula has fluctuated in the direction of an increase where the cash flow took longer in 2018, when compared to the previous year. Accounts receivable management at Agung Podomoro Land and Alam Sutera Reality has fluctuated, where in 2018 the accounts receivable turned into sales longer than the previous year. The inventory management companies of Agung Podomoro Land and Bekasi Asri Pemula have fluctuated, where in 2018 the period for changing inventory to sales was longer than the previous year. The debt management companies of Agung Podomoro Land, Alam Sutera Reality, and Bekasi Asri Pemula have fluctuated, where in 2018 the length of trade debt was paid off longer than the previous year. There is a decline in the level of profitability and working capital management which is increasingly necessary to analyze the relationship of working capital management to the level of profitability of property and real estate companies.

Research conducted by Abuzayed [2] concluded that the cash conversion cycle (CCC) have had a positive impact and significant impact on profitability. Research by Raheman et al. [5] concluded that the cash conversion cycle (CCC) had a negative and significant effect on profitability. Research conducted by Bhunia [11] concluded that the cash conversion cycle (CCC) has no effect on profitability. Previous research is still contradictory, so further research is needed to produce conclusions about the influence of cash conversion cycle (CCC) to profitability.

Research conducted by Abuzayed [2] concluded that the receivable collection period (RCP) have had a positive impact and significant impact on profitability. Research by Mabandla \& Makoni [3] concluded that the receivable collection period (RCP) have a negative influence and significant impact on profitability.

Research by Kusuma \& Bachtiar [12] concluded that the receivable collection period (RCP) has no effect on profitability. Previous research is still contradictory, so further research is needed to produce conclusions about the effect of the receivable collection period (RCP) on profitability.

Research conducted by Sin et al. [7] concluded that the inventory conversion period (ICP) has positive effects and significantly to profitability . Research by AlDebi'e [6] concluded that the inventory conversion period (ICP) have negative effects and significantly to Profitability. Research conducted by Talreja et al. [13] concluded that the inventory conversion period (ICP) had no effect on profitability. Previous research is still contradictory, so further research is needed to produce conclusions about the effect of the inventory conversion period (ICP) on profitability.

Research conducted by Mabandla \& Makoni [3] concluded that the account payable period (APP) have had a positive impact and significant on profitability. Research conducted by Abuzayed [2] concluded that the account payable period (APP) have negative effects and significantly to profitability. Research conducted by Kadumi \& Ramadan [14] concluded that the account payable period (APP) has no effect on profitability. Previous research is still contradictory, so further research is needed to produce conclusions about the effect of the account payable period (APP) on profitability.

According to Omoregie et al. [4], leverage can control the relationship between debt management (account payable period) and profitability based on the trade off theory. When leverage increases in the capital structure, liquid assets will shrink, which will result in additional debt for investment needs. An increase in debt can increase interest expenses so that it can reduce the company's profitability. Previous research conducted by Mun \& Jang [1] and Abuzayed [2] placed leverage as the control variable.

According to Sin et al. [7], firm size can control the relationship between cash and receivables management 
on profitability. When the firm size increases, the management of cash and accounts receivable will also increase so that it will increase the company's profitability. Previous research conducted by $\operatorname{Sin}$ et al. [7], Mun \& Jang [1], and Abuzayed [2] placed firm size as the control variable.

According to Simon et al. [9], sales growth can explain that management will adopt lower working capital to increase investment in sales. Sales growth can control inventory management because when sales are high, inventory must be streamlined, whereas if sales decline, inventory will be reduced. This is done to reduce the impact of costs due to the accumulation of goods in the warehouse that can put the company's profitability at risk. Previous research conducted by Simon et al. [9] and Sin et al. [7] placed sales growth as the control variable.

Based on the phenomenon of working capital on profitability, namely by fluctuating changes in working capital and profitability, as well as the many differences in research results, further research must be carried out. Researchers are interested in conducting research with the title "The Effect of Working Capital on Profitability in Property and Real Estate Companies Listed on the Indonesian Stock Exchange (IDX)".

\subsection{Trade Off Theory}

According to Raheman et al. [5], the trade off theory explains that profitability is very important if working capital management is not provided because of certain considerations so that the company can be said to be failing and will face bankruptcy. Based on the trade off theory, working capital management must be maximized to obtain a high level of profitability.

According to Jama [15], cash management that can require the use of cash must be maintained by assessing the possibility of keeping too much cash and trading costs for planning and monitoring cash flow needs from time to time. Cash management in working capital management is carried out effectively so that it is not used for useless investments, which will later become a burden for the company. Containment of cash flow (cash flow) when working capital is low will result in low operations but the use of high cash flow can create excessive investment which will increase company costs.

\subsection{Pecking Order Theory}

According to Sin et al. [7], the pecking order theory explains that there are costs to external financing and increased attention to creditors and shareholders, so companies must use internal resources to get financing before looking for external resources. A higher debt increase for more efficient operations can be done if internal funding sources are no longer able to meet all of the company's operational activities. The pecking order theory explains that company management will use all sources of capital such as debt and capital so that operational activities can continue.
According to Husnan [16], based on the pecking order theory, companies must balance the benefits and sacrifices that arise as a result of using debt. Companies can use debt as long as it has great benefits, but if the sacrifice is very high, the debt must be stopped. Companies must determine the most preferred source of funding that minimizes costs.

\subsection{Profitability}

According to Abuzayed [2], profitability is a decision made regarding operations that have a very important role in business. Profitability can describe management performance, namely being able to increase company profits in the financial reporting period.

According to Mabandla \& Makoni [3], the profitability ratio is production against financial performance measurements such as return on assets which measures income before tax based on total assets. Profitability ratios can tell about the asset base or other indicators used by the company to generate profits. According to Kasmir [17], the measurement of the profitability ratio is:

ROA $=\frac{\text { Profit after interest and tax }}{\text { Total Assets }}$

\subsection{Working Capital}

According to Sin et al.[7], the importance of working capital is to ensure the use of capital to generate profitability in the future. Working capital management is the integration of components of the overall strategy towards the efficient use of capital to create corporate value in the future. Measurement of working capital can be done using cash, accounts receivable, inventory, and debt management. According to Sin et al. [7], the measurement of working capital is:

1) Cash Conversation Cycle

The cash conversion period (CCC) is a measure that is very commonly used in measuring the efficiency of working capital. A longer investment period in working capital will force the company to seek external financing which is always associated with higher costs compared to its internal resources. The formula used is:

$\mathrm{CCC}=\mathrm{ICP}+\mathrm{RCP}-\mathrm{APP}$

Information :

ICP = Inventory Conversion Period

RCP = Receivable Collection Period

APP = Account Payable Period

2) Receivable collection period

Receivable collection period (RCP) is the management of company receivables so that they do not accumulate too much so that it will interfere with sales in the long term. The formula used is: average accounts receivable*365 
3) Inventory conversion period

Inventory conversion period (ICP) is the management of company inventory which results in changes in company value. The formula used is: $\mathrm{ICP}=\frac{\text { inventory average } * 365}{\text { cost of goods sold }}$

4) Account payable period

Account payable period (APP) is the management of company debt. The formula used is:

$$
\mathrm{APP}=\frac{\text { Account payable average*365 }}{\text { cost of goods sold }}
$$

\subsection{Control Variable}

Based on Mun \& Jang [1] research, the control variables used to control the relationship between working capital variables and profitability are:

a. Leverage

According to Omoregie et al [4], leverage can control the relationship between debt management (account payable period) and profitability based on the trade off theory. When leverage increases in the capital structure, liquid assets will shrink, which will result in additional debt for investment needs. An increase in debt can increase interest expenses so that it can reduce the company's profitability. According to Mun \& Jang [1], the formula used to measure leverage is:

$\mathrm{LEV}=\frac{\text { Total Debt }}{\text { Total Assets }}$

\section{b. Firm Size}

According to Sin et al. [7], firm size can control the relationship between cash and receivables management on profitability. When the firm size increases, the management of cash and accounts receivable will also increase so that it will increase the company's profitability. According to Sin et al. [7], the formula used to measure firm size is:

$$
\text { SIZE }=\text { LNTotal Assets }
$$

\section{c. Sales Growth}

According to Simon et al. [9], sales growth can explain that management will adopt lower working capital to increase investment in sales. Sales growth can control inventory management because when sales are high, inventory must be streamlined, whereas if sales decline, inventory will be reduced. This is done to reduce the impact of costs due to the accumulation of goods in the warehouse that can put the company's profitability at risk. According to Mun \& Jang [1], the formula used to measure sales growth is:

$\mathrm{SG}=\frac{\text { Sales t }- \text { Sales t-1 }}{\text { Sales } \mathrm{t}-1}$

\subsection{Conceptual Framework}

The research framework shows the effect of the independent variable on the dependent variable, the dependent variable in this study is profitability. Profitability is the company's ability to generate profits based on the value of its investment. The independent variable in this study is working capital.

Trade off theory explains that profitability is very important if working capital management is not given due to certain considerations so that the company can be said to be a failure and will face bankruptcy. The pecking order theory explains that there are costs to external financing and increased attention to creditors and shareholders, so the company must use internal resources to get financing before seeking external resources.

Working capital is measured through cash management (cash conversion cycle), receivable management (receivable collection period), inventory management (inventory conversion period), and debt management (account payable period). Cash management describes the management of cash flow where management must manage the net flow efficiently and effectively to improve company operations. The better cash management, the more efficient the use of funds to support these operations. Good cash management can reduce the cost of finding other sources of external financing to increase support for operations. The better cash management, the company is considered capable of controlling cash flow on the value of investment in working capital so that it is expected to increase the company's profitability.

Inventory management must be able to manage the number of items available in the warehouse because it will have a negative impact, such as a pile of items in the warehouse that is held for a certain period of time so that the potential for sales to become cash flow is longer. In order to realize a well and stable inventory, the company must apply a realistic inventory management concept that can be accepted by various parties.

Debt management must be able to manage debt and its use because if the debt is too large it will result in higher interest expenses so that profits will decrease. However, if debt management is too low, the company will have difficulty funding, resulting in reduced operations which will reduce revenue.

Leverage can control the relationship between debt management (account payable period) and profitability. Firm size can control the relationship between cash and receivables management on profitability. Sales growth can explain that management will adopt lower working capital to increase investment in sales. Sales growth can control inventory management because when sales are high, inventory must be streamlined, whereas if sales decline, inventory will be reduced. To provide a clear picture, the conceptual framework of this study can be seen in the following figure : 


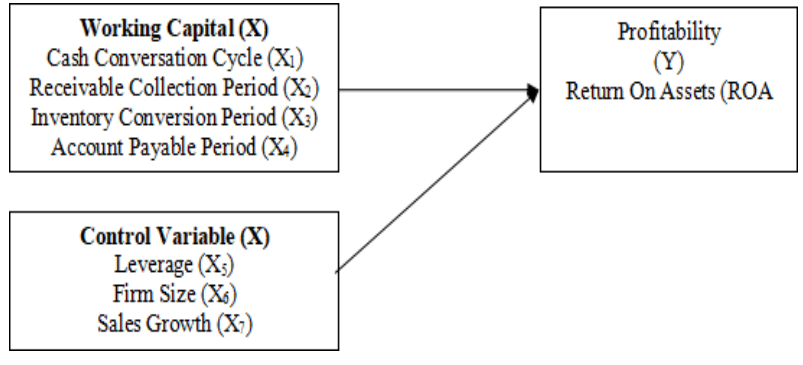

Figure 1. Conceptual Framework

\subsection{Hypothesis}

Based on the background of the problem, theory and previous research regarding working capital on previous profitability, a hypothesis can be formulated in this study, namely:

H1: Working capital as measured by cash management (cash conversion cycle) has a significant effect on profitability.

$\mathrm{H} 2$ : Working capital as measured by receivables management (receivable collection period) has a significant effect on profitability.

H3: Working capital as measured by inventory management (inventory conversion period) have a significant effect on profitability.

H4: Working capital as measured by debt management (account payable period) has a significant effect on profitability.

\section{METHOD}

This type of research is an associative research. The population in this study were property and real estate companies listed on the Indonesia Stock Exchange (IDX) for the period 2014 to 2018, totaling 82 companies. In order for the research to be more focused with accurate data, research samples were taken. The sample is part of the number and characteristics of the population. The research sample was taken by using purposive sampling method. Sample determination criteria:

a. Property and real estate sector companies listed on the Indonesian Stock Exchange (IDX) for the period 2014-2018.

b. Property and real estate sector companies that report complete annual reports from 2014-2018.

Based on the research sample criteria, of the 82 total population of the company, a sample of 46 companies was obtained that was studied for five years. So thatthe total research sampleis 230 (46 companies multiplied by 5 years of research). This study aims to see the effect of working capital variables on company profitability so that it is measured through ordinary least square (OLS) analysis. The equation for Ordinary Least Square (OLS) is:

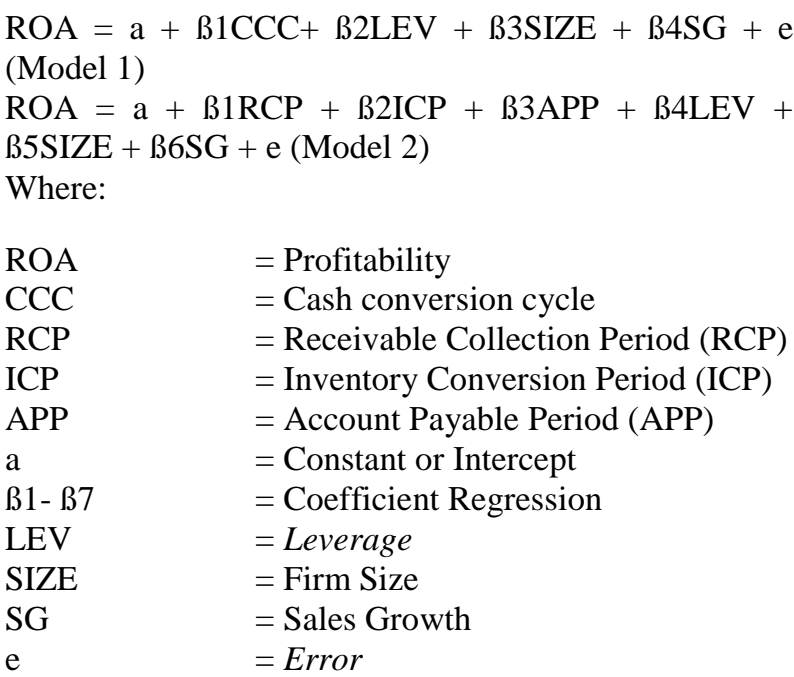

\section{RESULTS AND DISCUSSION}

\subsection{Research Results}

The use of descriptive analysis aims to see the lowest average value and the highest standard deviation of the data under study. The results of the descriptive analysis test in this study are in Table 2.

Based on table 2, the profitability variable has the lowest value of Rp. -0.24 means that the lowest company profit has a loss of Rp. 0.24 of each asset held. The lowest value lies in the Nusa Construction Engineering company (DGIK) in 2016. The highest value is $\mathrm{Rp}$. 0.38 means that the highest company profit is Rp. 0.38 of each asset held. The highest value lies in the 2016 Fortune Mate Indonesia (FMII) company. The average value is Rp. 0.053 means that the company's average profit is Rp. 0.053 of each asset held. The standard deviation of profitability is Rp. 0.06 .

The cash management variable (cash conversion cycle) has the lowest value of -217.68 days, which means that the company's ability to convert cash into finished goods and return to cash is the lowest of -217.68 days or 7 months at the company Adhi Karya (Persero) (ADHI). 2015. The highest value of 9,052.43 days means that the company's ability to convert cash into finished goods and return to cash is the highest of $9,052.43$ days or 24.80 years in the company Greenwood Sejahtera (GWSA) in 2015. The average value is 816,84 days means that the average company ability to convert cash into finished goods and back into cash is 816.84 days or 2.23 years. The standard deviation of cash management (cash conversion cycle) is 1,298.47 days. 
Table 2: Descriptive Analysis Test Results

\begin{tabular}{|l|r|r|r|r|r|}
\hline \multicolumn{7}{|c|}{ Descriptive Statistics } \\
\hline & $\mathrm{N}$ & Minimum & Maximum & \multicolumn{1}{c|}{ Mean } & Std. Deviation \\
\hline Profitability & 230 & -.24 & .38 & .0533 & .06399 \\
\hline Cash conversion cycle (CCC) & 230 & -217.68 & 9052.43 & 816.84 & 1298.47821 \\
\hline Receivable Collection Period (RCP) & 230 & .06 & 619.14 & 83.3831 & 97.78930 \\
\hline Inventory Conversion Period (ICP) & 230 & .00 & 9522.46 & 818.54 & 1321.86922 \\
\hline Account Payable Period (APP) & 230 & .00 & 584.61 & 85.0894 & 89.01581 \\
\hline Leverage & 230 & .03 & 4.02 & .4452 & .30652 \\
\hline Firm Size & 230 & 9.79 & 18.64 & 15.3595 & 1.54296 \\
\hline Sales Growth & 230 & -.91 & 8.43 & .1603 & .82029 \\
\hline Valid N (listwise) & 230 & & & & \\
\hline
\end{tabular}

The receivable management variable (receivable collection period) has the lowest value of 0.06 days, which means that the company's ability to collect receivables is at least 0.06 days from the Bekasi Asri Pemula (BAPA) company in 2018. The highest value is 619.14 days, which means the company's ability to collect accounts receivable for a maximum of 619.14 days or 1.69 years at Bakrieland Development (ELTY) in 2015. The average value is 83.38 days, which means that the average company's ability to collect receivables is 83.38 days. The standard deviation of receivables management (receivable collection period) is 97.78 days.

The lowest value of the inventory conversion period is 0 days, meaning that the time it takes the company to convert raw materials into finished goods until it is sold is 0 days at the Nusa Raya Cipta (NRCA) company in 2014-2017. The highest value of 9,522.46 days means that the time it takes the company to convert raw materials into finished goods until it is sold is 9,522.46 days or 26.08 years for the Greenwood Sejahtera (GWSA) company in 2015. 54 days means that the average time required for the company to convert raw materials into finished goods until they are sold is 818.54 days or 2.24 years. The standard deviation of inventory management (inventory conversion period) is $1,321.86$ days.

The lowest value of the debt management variable (account payable period) is 0 days, which means that the time required for the company to pay debt is at least 0 days at Metro Realty (MTSM) companies from 2014 to 2018, Rista Bintang Mahkota Sejati (RBMS) in 2016, and Sitara Propertindo. (TARA) from 2017 to 2018. The highest value of 584.61 days means that the time required for the company to pay debts is at the highest 584.61 days or 1.60 years at the Greenwood Sejahtera (GWSA) company in 2015. The average value is 85.08 days means that the average time required for the company to pay debts is 85.08 days. The standard deviation of debt management (account payable period) is 89.01 days.

The lowest value of the leverage variable is Rp. 0.03 means that the company's debt is at least Rp. 0.03 of each asset owned by the company Rista Bintang Mahkota Sejati (RBMS) in 2016. The highest value is Rp. 4.02 means that the company's debt is at least Rp. 4.02 of each asset owned by the company Bekasi Asri Pemula (BAPA) in 2016. The average value is Rp. 0.445 means that the company's average debt is Rp. 0.445 of each asset held. The standard deviation of leverage is $\mathrm{Rp}$. 0.306 .

The variable company size (firm size) has the lowest value of 9.79 times the Bekasi Asri Pemula (BAPA) company in 2016. The highest value is 18.64 times the Waskita Karya (WSKT) company in 2018. The average value is 15.35 . times and the standard deviation of 1.54 times.

The lowest sales growth variable is Rp. -0.91 means a decrease in sales of Rp. 0.91 of the previous total sales at the Fortune Mate Indonesia (FMII) company in 2017. The highest value was Rp. 8.43 means that the highest increase in sales is Rp. 8.43 of the previous total sales at the Bukit Darmo Property (BKDP) company in 2014. The average value was Rp. 0.160 means the average increase in sales of Rp. 0.160 of the previous total sales. The standard deviation of sales growth is Rp. 0.820 .

\subsection{Uji Ordinary Least Square (OLS)}

The Ordinary Least Square (OLS) test functions to see the changes in the dependent variable when tested using the independent variable. The ordinary least square (OLS) test results are: 
Table 3: Ordinary Least Square (OLS) Test Results

\begin{tabular}{|c|c|c|c|c|c|c|c|c|}
\hline \multirow{2}{*}{ Variable } & \multicolumn{4}{|c|}{ Model 1} & \multicolumn{4}{|c|}{ Model 2} \\
\hline & B & Error & $\mathrm{T}$ & $\operatorname{sig}$ & B & Error & $\mathrm{t}$ & $\operatorname{sig}$ \\
\hline (Constant) & $-0,065$ & 0,085 & $-0,770$ & 0,442 & $-0,120$ & 0,077 & $-1,548$ & 0,123 \\
\hline Cash conversion cycle (CCC) & 0,001 & 0,008 & 0,088 & 0,930 & & & & \\
\hline Receivable Collection Period (RCP) & & & & & $-0,0003$ & 0,00008 & $-4,335$ & 0,000 \\
\hline Inventory Conversion Period (ICP) & & & & & 0,0004 & 0,0004 & 0,984 & 0,326 \\
\hline Account Payable Period (APP) & & & & & $-0,0002$ & 0,00009 & $-2,288$ & 0,023 \\
\hline Leverage & 0,023 & 0,026 & 0,872 & 0,384 & 0,032 & 0,025 & 1,277 & 0,203 \\
\hline Firm Size & 0,017 & 0,005 & 3,189 & 0,002 & 0,023 & 0,005 & 4,493 & 0,000 \\
\hline Sales Growth & 0,024 & 0,010 & 2,488 & 0,014 & 0,022 & 0,009 & 2,393 & 0,018 \\
\hline
\end{tabular}

The regression equation in model 1 or using control variables is:

ROA $=-0,065+0,001 \mathrm{CCC}+0,023 \mathrm{Lev}+0,017$ Size + $0,024 \mathrm{SG}+\mathrm{e}$

The explanation of the regression equation above is:

a. The constant has a value of 0.065 (negative), if the cash conversion cycle, leverage, firm size and sales growth variables are constant, the profitability variable has decreased by 0.065 or $6.5 \%$.

b. The cash conversion cycle (CCC) variable has a regression coefficient value of 0.001 (positive), so the relationship formed is unidirectional. If the cash conversion cycle (CCC) increases by $1 \%$, the profitability also increases by 0.001 or $0.1 \%$.

c. The leverage variable has a regression coefficient value of 0.023 (positive), so the relationship formed is unidirectional. If the leverage increases by $1 \%$, the profitability will also increase by 0.023 or $2.3 \%$.

d. The firm size variable has a regression coefficient value of 0.017 (positive), so the relationship formed is unidirectional. If the firm size increases by $1 \%$, the profitability also increases by 0.017 or $1.7 \%$.

e. The sales growth variable has a regression coefficient of 0.024 (positive), so the relationship formed is unidirectional. If sales growth increases by $1 \%$, profitability will also increase by 0.024 or $2.4 \%$.

The regression equation in model 2 or using control variables is:

$\mathrm{ROA}=-0,120-0,0003 \mathrm{RCP}+0,0004 \mathrm{ICP}-0,0002 \mathrm{APP}+$ 0,032Lev + 0,023Size + 0,022SG + e

The explanation of the regression equation above is:

a. The constant has a value of 0.120 (negative), if the variables receivable collection period, inventory convention period, account payable period, leverage, firm size, and sales growth are constant, the profitability variable has decreased by 0.120 or $12 \%$. b. The variable receivable collection period (RCP) has a regression coefficient value of 0.0003 (negative), so the relationship formed is opposite. If the receivable collection period (RCP) increases by $1 \%$, the profitability decreases by 0.0003 or $0.03 \%$.

c. The inventory convention period (ICP) variable has a regression coefficient value of 0.0004 (positive), so the relationship formed is unidirectional. If the inventory convention period (ICP) increases by $1 \%$, the profitability will increase by 0.0004 or $0.04 \%$.

d. The account payable period (APP) variable has a regression coefficient value of 0.0002 (negative), so the relationship formed is in the opposite direction. If the account payable period (APP) increases by $1 \%$, the profitability decreases by 0.0002 or $0.02 \%$.

e. The leverage variable has a regression coefficient value of 0.032 (positive), so the relationship formed is unidirectional. If the leverage increases by $1 \%$, the profitability will also increase by 0.032 or $3.2 \%$.

f. The firm size variable has a regression coefficient value of 0.023 (positive), so the relationship formed is unidirectional. If the firm size increases by $1 \%$, the profitability also increases by 0.023 or $2.3 \%$.

g. The sales growth variable has a regression coefficient value of 0.022 (positive), so the relationship formed is unidirectional. If sales growth increases by $1 \%$, profitability will also increase by 0.022 or $2.2 \%$.

\subsection{Model Feasibility Test}

The feasibility test of the model used was the coefficient of determination test and the simultaneous $\mathrm{F}$ test. The results of the model feasibility test are:

\section{a. Determination Coefficient Test}

The coefficient of determination test is used to see the ability of the independent variable to provide an overview of the effect on the dependent variable. The results of the determination coefficient test are:

\begin{tabular}{|c|c|}
\hline \multicolumn{2}{|c|}{ Adjusted R Square } \\
\hline Model 1 & Model 2 \\
\hline 0,052 & 0,160 \\
\hline
\end{tabular}

Based on table 4, the adjusted $\mathrm{R}$ square value in testing model 1 or not using control variables is 0.052. The magnitude of the influence of the cash conversion cycle variable, leverage, firm size, and sales growth on the profitability variable is $5.2 \%$ while the remaining $94.8 \%$ is influenced by other variables that are outside the research model. 
Based on table 4, the adjusted $\mathrm{R}$ square value in testing model 2 or by using the control variable is 0.160 . The magnitude of the influence of the variable receivable collection period, inventory convention period, account payable period, leverage, firm size, and sales growth on the profitability variable is $16 \%$ while the remaining $84 \%$ is influenced by other variables that are outside the research model. b. F Test

The $\mathrm{F}$ test is used to measure the presence or absence of overall influence between the independent variables on the dependent variable. If the significance value $<0.05$, the hypothesis is accepted, meaning that there is an overall influence between the independent variables on the dependent variable. The results of the simultaneous $\mathrm{F}$ test in this study are:

\begin{tabular}{|r|c|c|r|}
\hline \multicolumn{2}{|c|}{ Model 1 } & \multicolumn{2}{c|}{ Model 2 } \\
\hline F & Sig & F & Sig \\
\hline 4,139 & 0,003 & 8,249 & 0,000 \\
\hline
\end{tabular}

Based on table 5, the $\mathrm{F}$ test results have a significant value of $0.003<0.05$, so the hypothesis is accepted. The conclusion is the cash conversion cycle, leverage, firm size, and sales growth variables have a significant effect on profitability together or as a whole.

Based on table 5 , the $\mathrm{F}$ test results have a significant value of $0.000<0.05$, so the hypothesis is accepted. The conclusion is that the variables receivable collection period, inventory convention period, account payable period, leverage, fim size, and sales growth have a joint or overall significant effect on profitability.

\subsection{Hypothesis Testing}

Hypothesis testing in this study uses a partial $t$ test in order to see the effect of the independent variable on the dependent variable partially. The assumptions used if the significant value $<0.05$ then the hypothesis is accepted or the independent variable has a significant effect on the dependent variable. The results of the partial t test in the study are based on table 10, namely:

a. Model 1

Based on table 3, the cash management variable (cash conversion cycle) has a coefficient of 0.001 with a significance value of $0.930>0.05$, so the hypothesis is rejected. The conclusion obtained is the cash management variable (cash conversion cycle) has a positive and insignificant effect on profitability.

The leverage variable has a coefficient of 0.023 with a significance value of $0.384>0.05$, so the hypothesis is rejected. The conclusion obtained is that the leverage variable has a positive and insignificant effect on profitability.

The firm size variable has a coefficient of 0.017 with a significance value of $0.002<0.05$, so the hypothesis is accepted. The conclusion obtained is that the firm size variable has a positive and significant effect on profitability.

The sales growth variable has a coefficient of 0.024 with a significance value of $0.014<0.05$, so the hypothesis is accepted. The conclusion obtained is that the sales growth variable has a positive and significant effect on profitability.

b. Model 2

Based on table 3 , the receivable collection period has a coefficient of -0.0003 with a significance value of $0.000<0.05$, so the hypothesis is accepted. The conclusion is that the receivable collection period has a negative and significant effect on profitability. The test results show that the control variable is able to control the relationship between receivable management and profitability.

The inventory conversion period variable has a coefficient of 0.0004 with a significance value of $0.326>0.05$, so the hypothesis is rejected. The conclusion is that the inventory conversion period has a positive and insignificant effect on profitability. The test results explain that the control variable is unable to control the relationship between inventory management and profitability because it does not result in the hypothesis being accepted.

The debt management variable (account payable period) has a coefficient of -0.0002 with a significance value of $0.023<0.05$, so the hypothesis is accepted. The conclusion obtained is that the debt management variable (account payable period) has a negative and significant effect on profitability. The test results explain that the control variable is able to control the relationship of debt management (account payable period) to profitability because it is able to result in the hypothesis being accepted.

The leverage variable has a coefficient of 0.032 with a significance value of $0.203>0.05$, so the hypothesis is rejected. The conclusion obtained is that the leverage variable has a positive and insignificant effect on profitability.

The firm size variable has a coefficient of 0.023 with a significance value of $0.000<0.05$, so the hypothesis is accepted. The conclusion obtained is that the firm size variable has a positive and significant effect on profitability.

The sales growth variable has a coefficient of 0.022 with a significance value of $0.018<0.05$, so 
the hypothesis is accepted. The conclusion obtained is that the sales growth variable has a positive and significant effect on profitability.

\subsection{Discussion}

H1: The Effect of Cash Management (Cash Conversion Cycle) on Profitability

The hypothesis in this study is that working capital as measured by cash management or cash convention cycle (CCC) has a significant effect on profitability. The test results concluded that the working capital variable measured using cash management or cash conversion cycle (CCC) had a positive and insignificant effect on profitability using the control variable. Cash management is the management of the company's cash flow so that it can affect operations in a certain amount. Basically, the management of companies in the property and real estate sector is used to manage the investment value of the company's products, it's just that the proportion is still too small so that it hasn't been able to affect the company's profitability. This happens because the period of inventory turns into revenue over one year. As a result, income is not counted in the accounting period, which results in no effect of cash management on company profitability.

However, the results of this study support the results of previous studies conducted by Mabandla \& Makoni [3], Bhunia [11], Talreja et al. [13], and Kusuma \& Bachtiar [12] which concluded that cash management or cash conversion cycle (CCC) has no effect on profitability. The results of this study do not support previous research conducted by Mun \& Jang [1], Abuzayed [2], Sin et al. [7], Raheman et al. [5], Simon et al. [9], Al-Debi'e [6], and Kaddumi \& Ramadan [14] concluded that cash management or cash conversion cycle (CCC) has a significant effect on profitability.

The results of this study do not support the trade off between risk and return theory which explains that working capital management will focus on the quality of current assets and consider the opportunities between risk and return. The quality of current assets will depend largely on the current asset composition and the time period required to convert individual assets into cash. Cash management is part of the management of current assets which carries a high level of risk if not managed properly.

Effective cash management can create effectiveness and efficiency in cash flow so that it does not interfere with the company's operational costs. Balance in cash management cannot protect the company from risks such as lack of funding sources as a result of inefficient cash management.

The average development of cash management in the property and real estate sector is 816.64 days. Cash management takes 816.64 days or 2.23 years so that the company is able to cover its trade payable based on its current assets. The average company in the property and real estate industry has a profitability level of $5.3 \%$

H2: The Effect of Receivables Management (Receivable Collection Period) on Profitability

The hypothesis in this study is that working capital as measured by receivables management (receivable collection period) has a significant effect on profitability. The test results concluded that the working capital variable measured using receivables management (receivable collection period) had a negative and significant effect on profitability using the control variable. Accounts receivable management is the management of company receivables which can affect revenue, which in turn causes changes in profitability. Accounts receivable management must be managed properly because receivables that are too piling up can cause losses for the company. A pile of accounts receivable causes disruption of the company's income, because receivables are revenue that is pending receipt. The better the management of accounts receivable, it can cause a reduction in company consumers so that it will affect income.

The results of this study support previous research conducted by Mun \& Jang [1], Abuzayed [2], Sin et al. [7], and Al-Debi'e [6] which concluded that receivables management (receivable collection period) has a significant effect on profitability. However, the results of this study do not support the results of previous research conducted by Talreja et al.[13] which concluded that receivables management (receivable collection period) has no effect on profitability.

The results of this study support the trade off between risk and return theory explaining that working capital management will focus on the quality of current assets and consider the opportunities between risk and return. The quality of current assets will depend largely on the current asset composition and the time period required to convert individual assets into cash. Taking into account current assets and all related items such as debt and capital will be able to increase company sales, and reduce costs so that it will increase profits

Accounts receivable management is part of the management of current assets that must be done carefully by the company. Receivables management that is managed too tightly can lead to reduced company revenue due to consumer dissatisfaction with credit purchases, but accounts receivable management that is too weak can cause piles of receivables which will prolong the conversion of receivables into cash or income. Both of these can reduce the company's profitability so that the management of accounts receivable has a negative impact on profitability.

The average development of accounts receivable management in the property and real estate sector is 83.38 days. This explains that the average company in the property and real estate sector takes 84 days a year 
to convert receivables into cash. The average company in the property and real estate industry has a profitability level of $5.3 \%$. The higher the accounts receivable management, the lower the company's profitability because the management of accounts receivable that is too strict can reduce revenue so that it will also reduce the company's profitability.

\section{H3: The Effect of Inventory Conversion Period on Profitability}

The hypothesis in this study is that working capital as measured by inventory management (inventory conversion period) has a significant effect on profitability. The test results concluded that the working capital variable measured using inventory management (inventory conversion period) had no effect on profitability using the control variable. Inventory management is the management of company inventory which can affect profitability. Property and real estate companies are not too concerned with inventory because most of the company's operations are renting and purchasing land and houses for industrial use with a design system. So the inventory does not affect the profitability of the company because there are no items piled up in the warehouse so that it does not cause warehouse costs which can significantly affect the company's profitability.

The results of this study support previous research conducted by Bhunia [11], Kaddumi \& Ramadan [14], Talreja et al. [13], and Kusuma \& Bachtiar [12] which concluded that inventory management has no effect on profitability. However, the results of this study do not support the results of previous studies conducted by Mun \& Jang [1], Abuzayed [2], Sin et al. [7], Mabandla \& Makoni [3], Raheman et al. [5], and Al-Debi'e [6] which concluded that inventory management period) has a significant effect on profitability.

The results of this study do not support the trade off between risk and return theory explaining that working capital management will focus on the quality of current assets and consider the opportunities between risk and return. The quality of current assets will depend largely on the current asset composition and the time period required to convert individual assets into cash. Taking into account current assets and all related items such as debt and capital will be able to increase company sales, and reduce costs so that it will increase profits.

Inventory management is part of the management of current assets which must be turned into cash within a predetermined time. The property and real estate industries have low inventories so that they do not affect the company's profitability because usually too much inventory can increase warehouse costs which can affect profitability. The property and real estate industry has a very low inventory because the company is engaged in the rental and construction of houses, factories and land with a design system so as to minimize the inventory of goods. However, there are some property and real estate companies that build buildings first and then sell them. With the high demand for property in Indonesia, the inventory of goods does not accumulate for too long.

The average development of inventory management in the property and real estate sector is 818.54 days. This explains that the average company in the property and real estate sector takes 819 days or 2.24 years to convert inventory into cash. The average company in the property and real estate industry has a profitability level of $5.3 \%$. The higher the inventory management, the less impact on the company's profitability.

\section{H4: Effect of Account Payable Period on Profitability}

The hypothesis in this study is that working capital, which is measured using account payable period, has a significant effect on profitability. The test results conclude that the working capital variable measured using debt management (account payable period) has a negative and significant effect on profitability using the control variable.

Debt management is the management of company investment that comes from debt or operational activities financed by debt. Debt incurs interest costs that must be paid by the company so that the existence of debt will reduce profitability in a certain period. In the property and real estate sector, the use of debt is more intended for company operations so that it requires a very large debt for its operational activities. The amount of debt that must be paid also causes a higher interest expense. The higher the interest expense, the lower the company's profitability.

However, the results of this study support the results of previous research conducted by Mun \& Jang [1], Abuzayed [2], Mabandla \& Makoni [3], Al-Debi'e [6] which concluded that debt management (account payable period) has a significant effect on profitability. The results of this study do not support previous research conducted by Raheman et al. [5], Kaddumi \& Ramadan [14], Talreja et al. [13], and Kusuma \& Bachtiar [12] which concludes that debt management (account payable period) has no effect on profitability.

The results of this study support the pecking order theory explaining that there are costs to external financing and increased attention to creditors and shareholders, so the company must use internal resources to get financing before seeking external resources. A higher debt increase for more efficient operations can be done if internal funding sources are no longer able to meet all of the company's operational activities.

Debt management is the management of funding sources originating from debt and operational management that is financed by debt. In general, debt can have an impact on company profitability because of the interest expense that must be incurred. However, without debt the company will also find it difficult to finance its operations so that it will have an impact on 
income which in turn will also affect the company's profitability.

The average development of debt management in the property and real estate sector is 85.08 days. This explains that the average company in the property and real estate sector takes 86 days to pay off debts from sales. The average company in the property and real estate industry has a profitability level of $5.3 \%$. The higher the debt management, the impact on the decrease in the company's profitability.

\section{CONCLUSIONS}

Based on the hypothesis testing that has been done, it can be concluded as follows:

1. The working capital variable measured using cash management or cash conversion cycle (CCC) has a positive and insignificant effect on profitability using the control variable.

2. The working capital variable measured using receivable management (receivable collection period) has a negative and significant effect on profitability using the control variable.

3. The working capital variable measured using inventory management (inventory conversion period) has no effect on profitability by using the control variable.

4. Working capital variables measured using debt management (account payable period) have a negative and significant effect on profitability using control variables.

Based on the research conclusions, suggestions are obtained that can be used as a reference for related parties. The suggestions for this research are:

1. We recommend that company management pay close attention to and closely monitor accounts receivable management and debt management in working capital management because it will reduce the company's profitability.

2. Investors must understand that in working capital management, the main things that must be considered are accounts receivable management and debt management because they have an impact on reducing the company's profitability. So that investors must choose a company that has good accounts receivable and debt management.

3. It is recommended that previous studies use other subsectors on the Indonesia Stock Exchange and add other variables that are likely to affect the company's profitability.

\section{REFERENCES}

[1] G. Mun, S., \& Jang, S. C. S. (2015). Working capital, cash holding, and profitability of restaurant firms. International Journal of
Hospitality Management, 48, 1-11. https://doi.org/10.1016/j.ijhm.2015.04.003

[2] B. Abuzayed. (2012). Working capital management and firms' performance in emerging markets: The case of Jordan. International Journal of Managerial Finance, 8(2), 155-179. https://doi.org/10.1108/17439131211216620Omor egie, O. K., Olofin, S. A., \& Ikpesu, F. (2019). Capital Structure and the Profitability-Liquidity Trade-Off. International Journal of Economics and Financial Issues, 9(3), 105-115. https://doi.org/10.32479/ijefi.7758

[3] Z. Mabandla, N., \& Makoni, P. L. (2019). Working capital management and financial performance: Evidence from listed food and beverage companies in South Africa. Academy of Accounting and Financial Studies Journal, 23(2), $1-10$.

[4] O. Omoregie, O., Olofin, S. A., \& Ikpesu, F. (2019). Capital Structure and the ProfitabilityLiquidity Trade-Off. International Journal of Economics and Financial Issues, 9(3), 105-115. https://doi.org/10.32479/ijefi.7758

[5] A. Rahema, Afza, T., Qayyum, A., \& Bodla, M. A. (2010). Working capital management and corporate performance of manufacturing sector in pakistan. International Research Journal of Finance and Economics, 47(September), 156169.

[6] A. 1-Debi'e, M. M. (2011). Working capital management and profitability: The case of industrial firms in Jordan. European Journal of Economics, Finance and Administrative Sciences, $36,75-86$.

[7] N. Sin, H., Chen, Y., Tze, S. O., \& Boon, H. T. (2017). The Impact of Working Capital Management on Firm 's Profitability: Evidence from Malaysian Listed Manufacturing Firms. International Journal of Economics and Financial Issues, 7(3), 662-670.

[8] Harmono. (2018). Manajemen Keuangan. Berbasis Balanced Scorecard Pendekatan Teori, Kasus, dan Riset Bisnis. Bumi Aksara.

[9] S. Simon., Sawandi, N., \& Abdul-Hamid, M. A. (2017). The quadratic relationship between working capital management and firm performance: Evidence from the Nigerian economy. Journal of Business and Retail Management Research, 12(1), 94-108. https://doi.org/10.24052/jbrmr/v12is01/tqrbwcmaf peftne 
[10] I. Fahmi. (2018). Pengantar Manajemen Keuangan: Teori dan Soal Jawaban. Alfabeta.

[11] Bhunia, A. (2012). Affiliation between Working Capital Management and Profitability. Interdisciplinary Journal of Contemporary Research In Business, 03(09), 957-968.

[12] Kusuma, H., \& Bachtiar, A. D. (2018). Working Capital Management and Corporate Performance: Evidence from Indonesia. Journal of Management and Business Administration. Central Europe, 26(2), 76-88.

https://doi.org/10.7206/jmba.ce.2450-7814.229

[13] Talreja, S., Ahmed, F., \& Ali, R. (2018). Nexus Between Working Capital Management and Sectoral Performance. Esensi: Jurnal Bisnis Dan Manajemen, 8(1), 89-104.

https://doi.org/10.15408/ess.v8i1.7075

[14] Kaddumi, T. A., \& Ramadan, I. Z. (2012). Profitability and Working Capital Management: The Jordanian Case. International Journal of Economics and Finance, 4(4). https://doi.org/10.5539/ijef.v4n4p217

[15] Jama, A. A. O. (2019). Effect Working Capitalmanagementpractices On Financial Performance in Manufucure Companies in Mogadishu Somalia. International Journal of Science and Research (IJSR), 8(2), 481-484. https://www.ijsr.net/archive/v8i2/ART20194847.p df

[16] Husnan, S. (2012). Dasar-Dasar Manajemen Keuangan (06 ed.). UPP STIM YPKN.

[17] Kasmir. (2018). Analisis Laporan Keuangan. PT. RajaGrafindo Persada. 